\title{
Measuring West-Africa Ports Efficiency Using Data Envelopment Analysis
}

\section{Bomboma Kalgora1*, Sidoine Yao Goli², Bomboma Damigou ${ }^{3}$, Hamadou Tahirou Abdoulkarim1, Kwame Kwadu Amponsem ${ }^{4}$}

\author{
${ }^{1}$ School of Economics and Management, Shanghai Maritime University, Shanghai, China \\ ${ }^{2}$ School of Management, Wuhan University of Technology, Wuhan, China \\ ${ }^{3}$ Institut Supérieur de Management, Dakar, Senegal \\ ${ }^{4}$ Regional Maritime University, Department of Transport, Accra, Ghana \\ Email: ^research.kb@outlook.com
}

How to cite this paper: Kalgora, B., Goli, S.Y., Damigou, B., Abdoulkarim, H.T. and Amponsem, K.K. (2019) Measuring West-Africa Ports Efficiency Using Data Envelopment Analysis. Journal of Transportation Technologies, 9, 287-308. https://doi.org/10.4236/jtts.2019.93018

Received: April 6, 2019

Accepted: May 27, 2019

Published: May 30, 2019

Copyright (C) 2019 by author(s) and Scientific Research Publishing Inc. This work is licensed under the Creative Commons Attribution International License (CC BY 4.0).

http://creativecommons.org/licenses/by/4.0/

\begin{abstract}
The present study measured the relative efficiency of five major commercial ports in West Africa, using three different Data Envelopment Analysis (DEA) methods, the CCR, BCC, and Windows I-C methods over the years 2005-2016. Seven input variables and one output variable were used in the model analysis. The CCR and BCC methods were used to evaluate the technical and scale efficiency while the Windows I-C method provided a comprehensive ranking of the studied ports. The results showed that the scale efficiency score of $89.53 \%$ indicated that on average the production scale of the ports had deviated from the most productive scale size (MPSS) by $10.47 \%$. These results revealed that the source of the overall inefficiency is due to scale rather than pure technical inefficiency. Hence, in order to improve the overall efficiency, the two scaled inefficient ports of Abidjan and Cotonou should adjust their scale of operations. Then, further investigations were conducted to detect correlations between various variables used in this study. The research found that the absence of any correlation for non-significant variables and negative correlation for the significant variables throughout time resulted from the fact that these variables were not fully utilized. Meaning that they were not efficiently used to boost the container throughput on a scale basis, the research also found that a pandemic or insecurity could easily impact seaports activities with the case of the Ebola outbreak which strucked the West African region from the year 2013 to 2016, or the terrorism threats which prevailed in the region around the year 2012. Thus, for ports to stand out in the present fiercely competitive environment, ports authorities ought to analyze their operational scale to identify whether or not the production size is fitting before further port capacity expansion.
\end{abstract}




\section{Keywords}

Container, Ports, Analysis, Scale Efficiency, Technical Efficiency, Data

Envelopment Analysis, West Africa

\section{Introduction}

\subsection{The Maritime Transport and Ports}

The maritime transport is fundamental for international trade and has made container ports to become important nodes in the transport supply chain, as they bridge supply and demand for containerized goods. The maritime transport has also allowed the transport of large quantities of goods at reasonable costs, therefore making container ports to become super-efficient and more competitive with regards to costs and services. According to Adam S. (1982) [1], the low cost of shipping favors the opening of new markets. The maritime transport infrastructure has strategic importance in line with market access services, global production, and trade competitiveness, economic development and social progress. Though, past centuries have seen various attempts to simplify transportation of cargo across the ocean often defeated by limitations in the development of appropriate cargo handling technology (Talley W. K., 2009) [2], there are several factors which have so far contributed to the evolution of container ports (Slack B., 1985) [3]; (Hayuth Y., 1988) [4]. Given the introduction of the container in the mid-1950s which has favored the handling operation of cargoes, the maritime transport has experienced great developments in terms of throughput growth history and in terms of increasing capacity of containerships. Consequently, the number of containers traded by this mode of transport has increased significantly from 50 million TEU in 1985 to 690 million in 2015 (World Bank Data, 2017) [5]. In terms of value, global seaborne container trade accounts for approximately $60 \%$ of all world seaborne trades, which was valued at around 12 trillion U.S. dollars in 2017. While the quantity of goods carried by containers has risen from 102 million metric tons in 1980 to about 1.85 billion metric tons in 2017 (Statista, 2017) [6]. This development in the industry has also led container vessels to increase their capacity. Between 1980 and 2016, the deadweight tonnage of containerships has grown from 11 million metric tons to 244 million metric tons (Statista, 2017) [6]. In addition, the capacity of containerships has increased from few hundred TEUs to thousands, and given birth to new transoceanic vessels that can carry above 21,000 TEUs (Rodrigue, J.-P., 2017) [7]. The increase in the size of containerships has placed significant pressure on ports. Therefore, ports have had to keep up with the changes by increasing water depths in approach channels and alongside berths and expanding channel widths to have sufficient vessel turning circles, and procuring larger quayside cranes with higher capacity outreach and lift height. In addition, ports have also had to expand terminal storage capacity and truck and railroad facilities to facilitate better flow of containers in and out of ports (van Dyck, G.K., 
2016) [8]. Henceforth, maritime transport is favored by the relocation of production units away from consumer markets. It comprises three basic elements such as the infrastructure of ports and container terminals, the ships and feeders that connect the seaports and lastly the systems that ensure the efficient operation of equipment and infrastructure. The maritime ports, in general, constitute one of the links in the multimodal transport chain. This research aims at the commercial maritime ports of five West Africa countries, Benin, Ivory Coast, Ghana, Nigeria, and Togo. The commercial seaports are the point of intersection of bi-directional goods flow in terms of import and export.

\subsection{Background of West Africa Ports}

West African ports of Ivory Coast, Ghana, Togo, Benin, and Nigeria are viewed as the most competitive and developed ports and they serve as the major gateways for the landlocked countries (LLCs) of West Africa (Kalgora B., 2019) [9]. In relatively close distance to each other, they have witnessed significant development in the past two decades. According to a study conducted by Van de Voorde, E. \& Winkelmans, W. (2002) [10] a port range is a geographically defined area comprising ports that serve much the same customers. West Africa is bordered by the Sahara Desert in the north with the Ranishanu Bend considered the northernmost part of the region. To the south and west, the Atlantic Ocean borders the region. The area covers approximately 5 million square kilometres (MOW, 2015) [11] with a population of approximately 340 million and a GDP per capita of USD 2500 (ECOWAS, 2015) [12]. According to the AFDB (2015) [13], the West African region had a development rate of $6 \%$ in 2014 . It is at the centre of the African continent economic and financial transformation. It is the quickest developing region in Africa and this growth is depicted in a wide range of divisions crosswise over various member states. In the most recent decades, maritime trade especially container trade has experienced an impressive growth rate along with increased demand for transport logistics services. The West African container throughput has expanded on average by $10 \%$ on yearly basis (Kalgora B., 2019) [14] with the populace and the GDP average growth at 3\% and $11 \%$ respectively (van Dyck G. K., 2015) [15].

This research study will assess five (5) main seaports along the West African drift which incorporates the Port of Abidjan in Ivory Coast, Tema in Ghana, Lomé in Togo, Cotonou in Benin and the Lagos Port Complex in Nigeria. It assesses their capabilities to attracting container throughput. The efficiency assessment will show the performance of seaports with regards to the resource utilization by analyzing inputs and outputs using the Data Envelopment Analysis (DEA). The remainder of this paper is organized as follows. Section 2 presents a review of literature pertaining to port efficiency and productivity. Section 3 presents the data and the methodology used in this paper. Section 4 discusses the DEA empirical results, while Section 5 conducts the ports variables analysis. The paper concludes in Section 6. 


\section{Review of Literature on Port Efficiency and Productivity}

Prior to containerization, the general cargo was handled by geared breakbulk vessels docked at piers that extended into the water. After the Second World War, with a significant increase in international trade, most ports around the world faced the problem of congestion. Cargoes were carried as breakbulk until the first load of containerized goods in 1966. They were shipped to Rotterdam and officially marked the beginning of containerization of international trade (Talley W. K., 2009) [2]. With advances in shipbuilding, associated cargo unitization systems were developed to reduce loading/unloading times at ports (Monteiro M., 2014) [16]. Consequently, this major breakthrough in the industry, led to the building of non-geared vessels, by redesigning containerships that would take advantage of economies of scale. Therefore in the same line of advancement in the industry, ports aspiring to handle more containers have had to invest more resources in quayside cranes, infrastructure and other related mobile capital.

According to Notteboom T. \& Rodrigue J. (2008) [17], there are three major phases in the container freight distribution system across the history of containerization internationalization. They are consequently as follows: The first phase, which is the introduction of containerization and its combination with maritime transport systems. As a result, this also led to efficiency improvements in port transshipment and inland service that became reliant on trucking. The second phase, which was more fundamental, related to the combination of containerization with inland transport systems including road and rail transport. Intermodal transport systems began to emerge in the late 1970s, thus leading to the development of a new generation of ports strongly influenced by containerization and intermodal transport. At that point in time, ports of which a huge part of functioning was based on information technology start emerging as logistics centres. The third phase is the current stage at which ports operate. They acting as functional nodes in supply chains through containerization propelled by intermodality. Ports have become super-efficient and more competitive with regards to costs and services.

\subsection{Port Efficiency}

Several careful literature reviews have disclosed numerous aspects that occupy port research involving efficiency evaluation (Wu Y. C. J. \& Goh M., 2010) [18]; (Demirel B., et al., 2012) [19]. Productivity and efficiency are the two main concepts related to economic performance. The concept of productivity is commonly defined as the ratio of the volume of output to the volume of input use (Liu Q., 2010) [20], whereas efficiency is noted as a relative concept where a firm's performance is compared to a benchmark. Similarly, Porter M. (1990) [21] states that the value of output produced by a unit of either labor or capital is termed as productivity which in turn is dependent on the efficiency of production and quality. At such, Productivity and efficiency have become very important elements to measure performance in the port sector (van Dyck G.K., 2015) 
[22]. Efficiency is defined by the Steering Committee for the Review of Commonwealth/State Service Provision as, the success with which organizations use an optimal amount of resources to produce outputs at a specific level of quality (Padilla M. \& Eguia R., 2010) [23]. Efficiency can be broken down further in terms of its technical and allocative nature.

\subsubsection{Technical Efficiency}

The Technical Efficiency (TE) represents the ability of a firm to minimize the waste by producing much output as technology input usage needed or utilizing as little input needed by technology and output production (Fried et al., 2008) [24]. Similarly, Padilla \& Eguia R. (2010) [23], explain that TE is the conversion of physical inputs (such as the services of employees and machines) into outputs relative to best practice. Thus, a firm or an organization operating at best practice is said to be 100 percent technically efficient. If operating below best practice levels, then the firm's technical efficiency is expressed as a percentage of best practice (Anguibi C. F. C., 2015) [25]. Technical efficiency can be either input-oriented or output-oriented; the choice of measurement depends on the particular nature of the industry. In the container port sector, port authority and the terminal operator can influence the production level through the use of commercial policies and different market strategies, but the provision of infrastructure is difficult to change over a short-term period. This led to the use of an output-oriented measure that features the maximum output able to be reached for a given input-mix (Liu Q., 2010) [20].

\subsubsection{Allocative Efficiency}

Coelli T. (1996) [26] explains that Allocative Efficiency (AE) is the ability of a firm to use the inputs in optimal proportion. Therefore, a firm can be said to be allocatively efficient when the inputs, given their prices, are used in a proportion that minimizes the cost of production. AE, similar to TE, can also be expressed as a percentage. A firm using its inputs in optimally obtaining a score of 100 percent. Cullinane K.W.F., et al., (2006) [27] state that in a competitive environment, ports should efficiently utilize their existing facilities in serving their customers, i.e., ports should ensure that the utilization of their current infrastructure, equipment and resources are economically and technically optimized. This will result in enhanced service quality by ultimately reducing vessel waiting time and translating into cost savings in the supply chain.

\subsection{Port Productivity}

Maritime access efficiency is a key element of port performance. The first point of maritime access is the anchorage where ships wait to berth; this is based on the availability of a slot. The lack of slots for berthing specific ships and problems with terminal productivity can result in long ships waiting times. Next, on the sea/land interface, terminal operation highlights the most common performance indicator in assessing port efficiency. For container ports and termi- 
nals, in particular, terminal operations involve the number of cranes available for use (how much loading/unloading is operationally possible) and crane performance (number of movements per crane per hour). For shipping lines, terminal operations are crucial to their overall operations since it affects the time ships spend at the port. Another component of performance includes the movement of cargo within the container yard. In container yard, operations are based on the terminal capacity, containers are stacked and container density is checked at a particular rate. For an efficient container yard performance, the appropriate space and equipment are essential as well as a proper organization because inefficient yard operations can affect the time duration trucks will spend at the yard.

\subsection{Efficiency and Productivity Measurement in Port Sector}

Several methodologies have been used with the aim of analyzing port efficiency and providing useful information for port development planning and strategy. The most widely used productivity and efficiency measurement approaches include the Data Envelopment Analysis (DEA). The application of the DEA method to the port industry is not new. Different variations of the DEA technique have been used to analyze port production in various regions worldwide. The advantages of the DEA method is that multiple inputs and outputs can be added to the model, and therefore has the capability of providing an overall evaluation of port performance (Wang T.F., et al., 2003) [28].

\subsubsection{DEA for Multi-Objective Analysis}

A range of studies have used the DEA model to assess efficiencies of ports at a specific point in time, either utilizing the DEA CCR or BCC models (van Dyck G.K., 2015) [22] in West Africa; (Anguibi C. F. C., 2015) [25] in West and Central Africa. Such studies have proved useful in identifying relationships between efficiency in ports and management policy-related issues, and the structures of the port. Authors like Martinez-Budria E., et al., (1999) [29] examined the efficiency of 26 ports in Spain using DEA-BCC models. They found that high complexity ports are associated with high efficiency. Utilizing both DEA-CCR and DEA-Additive models, (Tongzon J., 2001) [30] analyzed the efficiency of 4 Australian ports in addition to 12 other international container ports for the year 1996.

\subsubsection{DEA Efficiency over Time}

Assessing the efficiencies of ports and identifying the sources of inefficiency has seen windows analysis become more popular by utilizing panel data for a well-defined period (Degbe S.A., 2017) [31]. The assumption made is that observing the trend in efficiency over a specific period will offer more information on how resource utilization affects container throughput and terminals. Also, Cullinane K.P., et al., (2004) [32] applied different DEA methods based on cross-sectional and panel data analysis to container ports. The authors found that container port or terminal efficiency can be monitored over time providing policy makers and managers with useful insights to aid decision-making. The 
DEA window analysis model was then used to evaluate changes in container terminal efficiency over a period of 4 years for 11 terminals (Min H., \& Park B., 2005) [33]. The input data used included total quay length, the number of cranes, labor force, and container yard size, in addition to container throughput as the output. Al-Eraqi A.S., et al., (2008) [34] performed two DEA analyses, a simple DEA and a DEA window analysis concerning 22 ports located in the Middle-East and East-African region from 2000 to 2005. Their researches have used both panel-data and cross-sectional data and compared efficiency in terms of the scale of ports. They concluded that larger ports are often inefficient due to decreasing return to scale while smaller ports are more efficient for the opposite reason.

Efficiency has been addressed by port-related literature from many different perspectives (Ancor S-A., et al., 2016) [35]. Essentially, port efficiency analyses established relationships between inputs mainly a port's physical facilities and its labor force and outputs such as port throughput. In summary, the DEA model has been used extensively in port and terminal efficiency studies. There is a significant trend toward the use of the model to identify areas of inefficiency in both cross-sectional and panel data. Most studies have identified the usefulness of similar outputs and inputs for ports or terminals concerned. This ensures the model results are consistent and valid.

\section{Data and Methodology}

\subsection{Data Collection Techniques and Data Sources}

The study covers a period of 12 years from 2005 to 2016. The present research paper selected the 5 strategic countries container ports in the West African region. These container ports are identified as Decision Making Units (DMUs) and are shown in Table 1 for this purpose. They practically possess similar operational measures.

The competitive analysis of these ports is carried out using the DEA Window I-C method. This method can be a useful tool for port managers and for researchers, providing a deeper insight into ports performances (Roll Y. \& Hayuth Y., 2006) [36]. Researches revealed an absence of consensus in the choice of the type of variables (inputs and outputs) used in the DEA model (Tongzon, J., 2001) [30]. Plainly, Cullinane K. P., \& Wang T.-F. (2006) [37] emphasize that the

Table 1. DEA decision making units.

\begin{tabular}{ccc}
\hline S/N & Country & Ports Name \\
\hline 1 & Cote d'Ivoire & Port of Abidjan \\
2 & Benin & Port of Cotonou \\
3 & Nigeria & Port of Lagos \\
4 & Togo & Port of Lomé \\
5 & Ghana & Port of Téma \\
\hline
\end{tabular}

Source: Processed by the Author. 
precise choice of inputs and output variables is critical to the evaluation of container ports terminals and undefined variables may lead to misleading conclusions about ports evaluation.

The research, therefore, intends to assess the operational efficiencies of the selected DMUs. Seven input variables and one output variable are selected, and the standard container size or TEU is used with regards to the output variable (see Table 2). In order to be consistent with the production framework, like in the previous studies applying DEA method (Munisamy, S. \& Singh, G., 2011) [38] (Anguibi C. F. C., 2015) [25], this research uses proxies to evaluate the port's competitiveness through the labour and capital inputs. As for the labour inputs, the number of handling equipment's such as quayside cranes, yard gantry cranes and reach stackers, are used as proxies. The quay length, the container throughput limit, the terminal area, and the draught are selected as proxies for capital, whereas, the container throughput is used as the only output in the study.

The inputs variables data listed in Table 2 (for data, see Appendix Table A1) were compiled from national and regional ports authorities association such as the Port Management Association of West \& Central Africa (PMAWCA., 2017) [39] while the output variable of each of the five DMUs, the container throughput (for data, see Appendix Table A1), is obtained from international institutions such as the World Bank (2017) [5], and for accuracy purpose, are double checked with other regional institutions namely the ECOWAS, and the WAEMU.

\subsection{DEA Mathematical Formulation and Objective Function}

The linear programming technique is used to find the set of coefficients ( $u$ 's and $v^{\prime} s$ ) that will give the highest possible efficiency ratio of outputs to inputs for the service unit being evaluated (Sherman H.D., \& Zhu J., 2006) [40].

$$
D M U_{j}=\text { service unit number } j
$$

$j=$ number of decision making units (DMU) being compared in the DEA analysis.

$\theta=$ efficiency rating of the decision making unit being evaluated by DEA.

Table 2. DEA inputs and output variables.

\begin{tabular}{|c|c|c|}
\hline & Variables & Measurement \\
\hline & Quay Length & Total quay length in meters (m) \\
\hline & Terminal Area & Total size of terminal in hectare $(\mathrm{Ha})$ \\
\hline & Quayside Cranes & Total number of quayside cranes \\
\hline \multirow[t]{4}{*}{ Inputs } & Yard Gantry Cranes & Total number of Gantry Cranes \\
\hline & Reach Stackers & Total number of Reach Stackers \\
\hline & Draught & Depth of Container Terminals (m) \\
\hline & Container Throughput Limit & Port Terminal Handling Capacity (TEU) \\
\hline Outputs & Container Throughput & Annual Cargo Throughput (TEU) \\
\hline
\end{tabular}

Source: Processed by the Author. 
$y_{i j}=$ amount of output $r$ used by service unit $j$.

$x_{i j}=$ amount of input $r$ used by service unit $j$.

$i=$ number of inputs used by the DMUs.

$r=$ number of outputs generated by the DMUs.

$u_{r}=$ coefficient or weight assigned by DEA to output $r$.

$V_{i}=$ coefficient or weight assigned by DEA to input $i$.

The function is subject to the constraint that when the same set of $u$ and $v$ coefficients is applied to all other service units being compared, no service unit (DMUs) will be more than efficient than 1. Charnes A., et al. (1978) [41] suggested the following mathematical programming for estimating the relative efficiency score of a particular DMU $j$ among similar $n$ entities being evaluated.

$$
\begin{gathered}
D M U_{j}=\frac{u_{1} y_{1 j}+u_{2} y_{2 j}+\cdots+u_{r} y_{r j}}{v_{1} x_{1 j}+v_{2} x_{2 j}+\cdots+v_{i} x_{i j}}=\frac{\sum_{r=1}^{s} u_{r} y_{r j}}{\sum_{i=1}^{m} v_{i} x_{i j}} \leq 1, j=1, \cdots, n \\
u_{r}, \cdots, u_{s}>0 \text { and } v_{i}, \cdots, v_{m} \geq 0 ; r=1, \cdots, s ; i=1, \cdots, m
\end{gathered}
$$

To solve the fractional mathematical programming problem, Equation (1) has been transformed into a linear programming model as written below:

$$
\begin{aligned}
\max & \sum_{r=1}^{S} u_{r} y_{r o} \\
\text { s.t. } & \sum_{r=1}^{S} u_{r} y_{r j}-\sum_{i=1}^{m} v_{i} x_{i j} \leq 0, j=1, \cdots, n \\
& \sum_{i=1}^{m} v_{i} x_{i 0}=1 \\
& u_{r}, v_{i} \geq 0
\end{aligned}
$$

To obtain the solution of Equation (3), the dual form has been considered and presented as follows:

$$
\begin{array}{ll}
\min & \theta \\
\text { s.t. } & \sum_{j=1}^{n} x_{i j} \lambda_{j}-\theta x_{i o} \leq 0, i=1, \cdots, m \\
& \sum_{j=1}^{n} y_{r j} \lambda_{j}-y_{r o} \geq 0, \quad r=1, \cdots, s \\
& \lambda_{j} \geq 0, \quad j=1, \cdots, n
\end{array}
$$

The CCR model given above follows an input-oriented approach that is the minimization of resources for a desired amount of outputs. The present study adopted an output-oriented approach in order to determine how a port could efficiently increase its throughput from a particular quantity of resources. Similar to the input-oriented CCR model formulation, the output-oriented CCR dual form is shown as follows in the Equation (4):

$$
\begin{array}{ll}
\max \phi & \\
\text { s.t. } & \sum_{j=1}^{n} x_{i j} \lambda_{j}-x_{i 0} \leq 0, i=1, \cdots, m \\
& \sum_{j=1}^{n} y_{r j} \lambda_{j}-\phi y_{r o} \geq 0, \quad r=1, \cdots, s \\
& \lambda_{j} \geq 0, j=1, \cdots, n
\end{array}
$$


Here $\varphi$ is the value of the relative efficiency score for each DMU being evaluated. By assuming that not all the decision-making units are operating at an optimal scale, the constraint presented below is added to the CCR, which is also called constant return to scale (CRS) model. This was conceived in order to obtain the BCC known as variable returns to scale (VRS) model introduced byBanker R.D., et al., (1984) [42].

$$
\sum_{j=1}^{n} \lambda_{j}=1
$$

The inverse of the estimated score of $\varphi$ gives the efficiency value for each DMU in both CCR and BCC model. By analyzing the efficiency of the DMUs under VRS assumptions, the scale efficiency (SE) of each DMU has been estimated using the efficiency scores obtained under CCR and BCC models. In fact, the efficiency observed under the CRS model is the overall measure of technical and scale efficiency; while the one deriving from the VRS model is pure technical efficiency (PTE). Hence, scale efficiency is calculated as follows in Equation (6):

$$
\mathrm{SE}=\frac{\mathrm{TE}}{\mathrm{PTE}}
$$

When SE equals to 1 this indicates scale efficiency and less than one demonstrates scale inefficiency. After the estimation of scale efficiency, the nature of returns to scale has been investigated to determine whether the scale inefficiency is related to either increasing (IRS) or decreasing (DRS) returns to scale. In order to find the nature of returns to scale, a comparison is made between the efficiency value given by a BCC model and the one calculated under the non-increasing returns to scale (NIRS) model. According to researchers, if the efficiency value of NIRS model is different from the BCC efficiency score, thus the DMU being assessed will exhibit increasing returns to scale. In the case both efficiency indices are equal, then the particular DMU experiences decreasing returns to scale (Banker R.D., et al., 2004) [43]. The NIRS model is obtained by adding the restriction written in Equation (7) instead of the constraint displayed in Equation (5) in the CCR model in Equation (4).

$$
\sum_{j=1}^{n} \lambda_{j} \leq 1
$$

As mentioned above, the standard DEA models CCR and BCC give the same efficiency value of 1 to all the efficient DMU. Consequently, it is not possible to identify among the efficient DMUs, the best performer. In order to provide ranking among the efficient ports, the window I-C is used with a windows length of 1.

\section{Empirical Results}

Each port is representative of a different DMU with 1 window per port in the analysis. The study used CCR, BCC and Window I-C DEA models under the assumption of output maximization to estimate the overall technical efficiency, 
pure technical efficiency scale efficiency and the nature of returns to scale and the $\mathrm{C}$-average for the five container ports under study. The results are summarized in Table 3.

The efficiency estimates of the CCR model is that the ports of Lagos, Lomé, and Tema are equal to 1 , revealing that these ports define the best practice frontier in terms of technical efficiency and performance. The efficiency scores of the remaining ports are less than 1 , demonstrating that they are relatively inefficient compared to the best practices ports. Considering the efficiency scores are derived from the BCC model, it is found that in addition to the efficient ports identified under the CCR model, the port of Abidjan and Cotonou have their efficiency score equal to 1 . This indicates that they are efficient in terms of resource utilization. Therefore, among the five studied ports, three, the ports of Tema, Lagos, and Lomé are efficient in the constant returns to scale (CRS), whereas the two remainings ports, Abidjan and Cotonou are operating efficiently under variable returns to scale (VRS). The average efficiency value obtained from the CRS model is $89.53 \%$, which is less than the average efficiency score estimated in the VRS model. The average scale efficiency scores, $89.53 \%$ which indicates that on average the ports actual scale of production has deviated from the most productive scale size (MPSS) by $10.47 \%$. On the whole, the results reveal that the source of the overall inefficiency is due to scale rather than pure technical inefficiency.

The ports of Lagos, Lomé, and Tema are scale and technically efficient with a score of 1 . Hence, these ports were operating at an optimal scale. Conversely, the ports of Abidjan and Cotonou, of which the efficiency scores are less than 1 in the CCR model, are efficient under BCC model. This demonstrates that they are technically efficient but scale inefficient. In other words, the ports were efficient in the utilization of input resources but they are either too small or too large regarding the activities they perform. Hence the two scaled inefficient ports Abidjan and Cotonou should adjust their scale of operations in order to move towards efficiency. Nevertheless, looking at the C-average compilation, from the Window I-C model, window 1 , it is seen that out of the five ports, only two exhibit value equal to 1 , Tema and Lagos.

Table 3. Efficiency results derived from DEA methods.

\begin{tabular}{cccccccc}
\hline \multirow{2}{*}{ Container Ports } & DEA-CCR & DEA-BCC & Window I-C (1) & SE & $\begin{array}{c}\text { Return } \\
\text { to Scale }\end{array}$ & Evaluation \\
\cline { 2 - 5 } & TE & PTE & C-Average & & 1 & CRS & efficient \\
Port of Tema & 1 & 1 & 1 & 1 & 1 & CRS & efficient \\
Port of Lagos & 1 & 1 & 1 & 0.8927 & 0.8701 & IRS & inefficient \\
Port of Abidjan & 0.8701 & 1 & 1 & 0.8239 & 1 & CRS & efficient \\
Port of Lome & 1 & 1 & 0.6981 & 0.6063 & IRS & inefficient \\
Port of Cotonou & 0.6063 & 1 & 0.8830 & 0.8953 & & \\
AVERAGE & 0.8953 & 1 & & & & \\
\hline
\end{tabular}

Source: Processed by the Author. 
The results derived from the analysis of the nature of returns to scale are summarized in the right-most column of Table 3. The outcome highlight is that three ports exhibited constant returns to scale (CRS). In addition, the two other ports are operating at increasing returns to scale, due to their small size of production and they need to enhance their efficiency by selecting a scaling up strategy, which would increase their scale of operations.

\section{Ports Variables Analysis}

A close look at the correlation matrix in Table 4 reveals a highly positive correlation between several variables: the quayside cranes and the quay length, between the quay length and the reach stackers, between terminal area and the

Table 4. DEA correlation coefficients in year 2016.

\begin{tabular}{|c|c|c|c|c|c|c|c|c|}
\hline & $\begin{array}{c}\text { Quay } \\
\text { Length }(\mathrm{m})\end{array}$ & $\begin{array}{l}\text { Terminal } \\
\text { Area }(\mathrm{Ha})\end{array}$ & $\begin{array}{c}\text { Quayside } \\
\text { Cranes }\end{array}$ & $\begin{array}{c}\text { Yard } \\
\text { Gantry } \\
\text { Cranes }\end{array}$ & $\begin{array}{l}\text { Reach } \\
\text { Stackers }\end{array}$ & $\begin{array}{l}\text { Draught } \\
(\mathrm{m})\end{array}$ & $\begin{array}{c}\text { Annual } \\
\text { Container } \\
\text { Throughput } \\
\text { Limit (TEU) }\end{array}$ & $\begin{array}{c}\text { Container } \\
\text { Throughput } \\
\text { (TEU) }\end{array}$ \\
\hline Quay Length (m) & 1 & & & & & & & \\
\hline Terminal Area (Ha) & 0.459 & & & & & & & \\
\hline (p-value) & 0.133 & 1 & & & & & & \\
\hline (t-stat) & 1.636 & & & & & & & \\
\hline Quayside Cranes & $0.891^{\star * *}$ & 0.388 & & & & & & \\
\hline (p-value) & 0.000 & 0.212 & 1 & & & & & \\
\hline (t-stat) & 6.231 & 1.333 & & & & & & \\
\hline Yard Gantry Cranes & 0.422 & $0.793^{* * *}$ & 0.228 & & & & & \\
\hline (p-value) & 0.172 & 0.002 & 0.476 & 1 & & & & \\
\hline (t-stat) & 1.471 & 4.121 & 0.740 & & & & & \\
\hline Reach Stackers & $0.957^{\star * *}$ & 0.194 & $0.843^{* * *}$ & 0.190 & & & & \\
\hline (p-value) & 0.000 & 0.546 & 0.001 & 0.555 & 1 & & & \\
\hline (t-stat) & 10.500 & 0.625 & 4.976 & 0.611 & & & & \\
\hline Draught $(\mathrm{m})$ & 0.479 & -0.428 & 0.360 & -0.474 & $0.7^{\star *}$ & & & \\
\hline (p-value) & 0.115 & -0.166 & 0.250 & -0.119 & 0.011 & 1 & & \\
\hline (t-stat) & 1.727 & -1.496 & 1.221 & -1.704 & 3.100 & & & \\
\hline $\begin{array}{c}\text { Annual Container Throughput } \\
\text { Limit (TEU) }\end{array}$ & 0.214 & $0.893^{\star * *}$ & 0.313 & $0.719^{* * *}$ & -0.071 & $-0.711^{* * *}$ & & \\
\hline (p-value) & 0.505 & 0.000 & 0.321 & 0.008 & -0.826 & -0.009 & 1 & \\
\hline (t-stat) & 0.692 & 6.309 & 1.044 & 3.280 & -0.226 & -3.201 & & \\
\hline Container Throughput (TEU) & 0.366 & $0.661^{\star *}$ & $0.627^{* *}$ & 0.470 & 0.152 & -0.482 & $0.858^{* * *}$ & \\
\hline (p-value) & 0.242 & 0.019 & 0.029 & 0.123 & 0.637 & -0.112 & 0.000 & 1 \\
\hline (t-stat) & 1.244 & 2.787 & 2.550 & 1.683 & 0.487 & -1.740 & 5.286 & \\
\hline
\end{tabular}

$* * *, * *,{ }^{*}$ imply significance of $1 \%, 5 \%$, and $10 \%$ respectively. Source: Processed by the Author. 
yard gantry cranes, between still the terminal area and the annual container throughput limit. There is also a significant correlation between the quayside cranes and reach stackers, the annual container throughput and the container throughput, the annual container throughput and yard gantry cranes. The positive correlation implies that as one variable increases, so does the other. Nevertheless, the matrix also reveals a high negative correlation between the annual container throughput and draught. All the mentioned variables are correlated among themselves at $1 \%$ of significance, demonstrating the impact they have on each other.

There is a strong positive correlation between the draught and the number the reach stackers. While the container throughput and the terminal area also see a correlation, as well as the number quayside cranes. These correlated variables are statistically significant at $5 \%$. As for the rest of the correlation matrix table, they are not statistically significant, meaning that there is no relationship, and thus the movement in one variable cannot be predicted from other corresponding variables.

Table 5, shows the compilation of correlation coefficients with their corresponding t-statistics and p-value over the period of 2005 to 2016. Proceeding by variable, the compilation table reveals a strong but negative correlation between the container throughput and quay length at 5\% of significance for years 2010 and 2011. Any other correlation coefficient with respect to container throughput and quay length within the time frame of our study, are not statistically significant. The terminal area, on the other hand, is highly correlated with the output variable from the year 2005 to 2011, and the year 2015, at $1 \%$ of significance. A positive correlation for the years 2012, 2014 and 2016 is also noticed at a 5\% of significance. The container throughput is positively correlated to the number of quayside cranes from 2005 to 2012 at $1 \%$ significance, while positively correlated at a 5\% significance for the years 2013, 2015 and 2016. The container throughput is highly correlated to the number of yard gantry cranes at $1 \%$ significance for the year 2013 while showing a 5\% significance for the years 2012 and 2015.

The number of reach stackers is positively correlated to container throughput from the year 2005 to 2011 at a $1 \%$ significance and is still correlated at a 5\% significance for the year 2012. Other correlation coefficients with respect to container throughput and the number of reach stackers are not significant. The draught is statistically significant at 1\% from 2012 to 2014, implying a high correlation with the container throughput. A 5\% significance for the years 2010 and 2011 is noticed. Other years within the study time period shown to be not conclusive. The container throughput and the annual container throughput limit are positive and highly correlated at $1 \%$ of significance over all the years of the study period. A significance of $1 \%$, shows a strong predictive relationship between the variables.

It is important to note that a very strong correlation has been noticed between the container throughput at the ports and the input variables. They are especially the terminal area, the number of quayside cranes, the number of reach stackers, 
Table 5. Compilation table of container throughput vs. input variables over time.

\begin{tabular}{|c|c|c|c|c|c|c|c|c|c|c|c|c|}
\hline & CT2005 & CT2006 & CT2007 & CT2008 & СТ2009 & CT2010 & CT2011 & CT2012 & СТ2013 & CT2014 & CT2015 & CT2016 \\
\hline $\begin{array}{l}\text { Quay Length } \\
(\mathrm{m})\end{array}$ & -0.326 & $-0.506^{\star}$ & $-0.552^{\star}$ & -0.440 & -0.265 & $-0.668^{* *}$ & $-0.696^{* *}$ & -0.032 & -0.270 & -0.181 & $0.535^{\star}$ & 0.366 \\
\hline (p-value) & -0.301 & -0.093 & -0.062 & -0.152 & -0.406 & -0.017 & -0.012 & -0.921 & -0.397 & -0.573 & 0.073 & 0.242 \\
\hline (t-stat) & -1.092 & -1.857 & -2.098 & -1.551 & -0.868 & -2.843 & -3.072 & -0.102 & -0.885 & -0.582 & 2.004 & 1.244 \\
\hline $\begin{array}{c}\text { Terminal Area } \\
(\mathrm{Ha})\end{array}$ & $0.937^{\star * *}$ & $0.875^{\star * *}$ & $0.836^{* * *}$ & $0.911^{\star * *}$ & $0.860^{\star * *}$ & $0.858^{\star * \star}$ & $0.780^{\star \star *}$ & $0.687^{* *}$ & $0.566^{\star}$ & $0.640^{* *}$ & $0.745^{\star * *}$ & $0.661^{* *}$ \\
\hline (p-value) & 0.000 & 0.000 & 0.001 & 0.000 & 0.000 & 0.000 & 0.003 & 0.013 & 0.055 & 0.025 & 0.005 & 0.019 \\
\hline (t-stat) & 8.531 & 5.742 & 4.819 & 6.999 & 5.339 & 5.298 & 3.952 & 2.996 & 2.173 & 2.635 & 3.535 & 2.787 \\
\hline $\begin{array}{l}\text { Quayside } \\
\text { Cranes }\end{array}$ & $0.867^{\star * *}$ & $0.960^{* * *}$ & $0.970^{* * *}$ & $0.932^{* * *}$ & $0.853^{\star * *}$ & $0.996^{\star * *}$ & $0.984^{* * *}$ & $0.901^{\star * *}$ & $0.681^{\star *}$ & 0.020 & $0.702^{\star \star}$ & $0.627^{* *}$ \\
\hline (p-value) & 0.000 & 0.000 & 0.000 & 0.000 & 0.000 & 0.000 & 0.000 & 0.000 & 0.015 & 0.951 & 0.011 & 0.029 \\
\hline (t-stat) & 5.508 & 10.986 & 12.792 & 8.177 & 5.169 & 35.542 & 17.741 & 6.578 & 2.946 & 0.062 & 3.119 & 2.550 \\
\hline $\begin{array}{l}\text { Yard Gantry } \\
\text { Cranes }\end{array}$ & $0.518^{*}$ & 0.235 & 0.139 & 0.342 & 0.414 & 0.109 & -0.016 & $0.585^{\star *}$ & $0.797^{\star * *}$ & $0.516^{*}$ & $0.634^{* *}$ & 0.470 \\
\hline (p-value) & 0.084 & 0.461 & 0.667 & 0.276 & 0.181 & 0.737 & -0.962 & 0.046 & 0.002 & 0.085 & 0.027 & 0.123 \\
\hline (t-stat) & 1.916 & 0.766 & 0.443 & 1.151 & 1.438 & 0.346 & -0.049 & 2.283 & 4.182 & 1.909 & 2.593 & 1.683 \\
\hline Reach Stackers & $0.859^{* * *}$ & $0.970^{* * *}$ & $0.985^{\star * *}$ & $0.938^{\star * *}$ & $0.911^{\star * *}$ & $0.959^{* * *}$ & $0.964^{* * *}$ & $0.639^{* *}$ & 0.443 & -0.438 & 0.313 & 0.152 \\
\hline (p-value) & 0.000 & 0.000 & 0.000 & 0.000 & 0.000 & 0.000 & 0.000 & 0.025 & 0.149 & -0.154 & 0.322 & 0.637 \\
\hline (t-stat) & 5.321 & 12.687 & 18.688 & 8.558 & 6.988 & 10.779 & 11.568 & 2.634 & 1.565 & -1.543 & 1.042 & 0.487 \\
\hline Draught (m) & $-0.536^{\star}$ & -0.488 & -0.467 & -0.470 & -0.488 & $-0.693^{* *}$ & $-0.667^{\star *}$ & $-0.709^{* * *}$ & $-0.936^{* * *}$ & $-0.911^{\star * *}$ & -0.408 & -0.482 \\
\hline (p-value) & -0.072 & -0.107 & -0.126 & -0.123 & -0.107 & -0.012 & -0.018 & -0.010 & 0.000 & 0.000 & -0.188 & -0.112 \\
\hline (t-stat) & -2.009 & -1.769 & -1.672 & -1.683 & -1.769 & -3.047 & -2.837 & -3.180 & -8.453 & -6.998 & -1.413 & -1.740 \\
\hline $\begin{array}{c}\text { Annual } \\
\text { Container } \\
\text { Throughput } \\
\text { Limit (TEU) }\end{array}$ & $0.986^{\star * *}$ & $0.929^{* * *}$ & $0.890^{* * *}$ & $0.965^{\star * *}$ & $0.942^{* * *}$ & $0.884^{\star * \star}$ & $0.811^{\star \star \star}$ & $0.981^{* * *}$ & $0.945^{\star * *}$ & $0.964^{\star * *}$ & $0.863^{\star * \star}$ & $0.858^{\star * *}$ \\
\hline (p-value) & 0.000 & 0.000 & 0.000 & 0.000 & 0.000 & 0.000 & 0.001 & 0.000 & 0.000 & 0.000 & 0.000 & 0.000 \\
\hline (t-stat) & 19.201 & 7.989 & 6.195 & 11.643 & 8.935 & 5.987 & 4.390 & 16.110 & 9.210 & 11.557 & 5.412 & 5.286 \\
\hline
\end{tabular}

$* * *, * *,{ }^{*}$ imply significance of 1,5 , and $10 \%$ respectively. Source: Processed by the Author.

and annual container throughput limit. The study here aims at identifying variables that in terms of efficiency and performance, drive and predict these ports container throughput. Having a pre-knowledge on these input variables is essential for container ports activities. Analyzing the variables on a yearly basis, revealed the terminal area, the quayside cranes and annual container throughput limit were the only significant variables correlated to the container throughput in the year 2016. However, if compared to the base year 2005, there four out of seven input variables were positive and statistically significant at $1 \%$.

A quick look at Figure 1, reveals a convergence of some input variables to a zero correlation from the year 2012; these were the annual container throughput 
limit, the quayside cranes, the terminal area, and the reach stackers. The quay length correlation to the container throughput also tended to zero from 2011 to 2012 and then from 2013 to 2014 . These shifts of the mentioned variables were largely due to the insecurity from terrorism threats which prevailed in West Africa at that time. The reach stackers, the quay length, the quayside cranes and the yard gantry cranes quayside cranes and terminal area moved toward a much better correlation with the container throughput from 2014 to 2015. All the variables experienced a downward slope in 2016 from the previous year, with the exception of draught inversely correlated to the container throughput.

A close look at the compiled p-value chart in Figure 2 gives a clear overview of the uncorrelated variables across years. These are the quay length, the yard gantry cranes, and the draught. Throughout the last four years of the study, reach stackers showed no significant correlation in explaining variation in the container throughput. Hence, the reliable and statistically significant in explaining changes in the container throughput, for the time period of the research, are the terminal area, quayside cranes, reach stackers, and the annual container throughput limit.

The frequency of very strong correlation, have been noticed between the container throughput and the terminal area, the quayside cranes, the reach stackers, and annual container throughput limit. With minor variations to be considered, five variables were found to reveal a long-run positive sign with the output variable; these were the annual container throughput limit, reach stackers, yard gantry cranes, quayside cranes, terminal area. On the other hand, the remaining two variables are exhibiting a negative long-run relationship with container throughput, these are quay length and draught.

\section{CONTAINER THROUGHPUT VS INPUT VARIABLES OVER TIME}

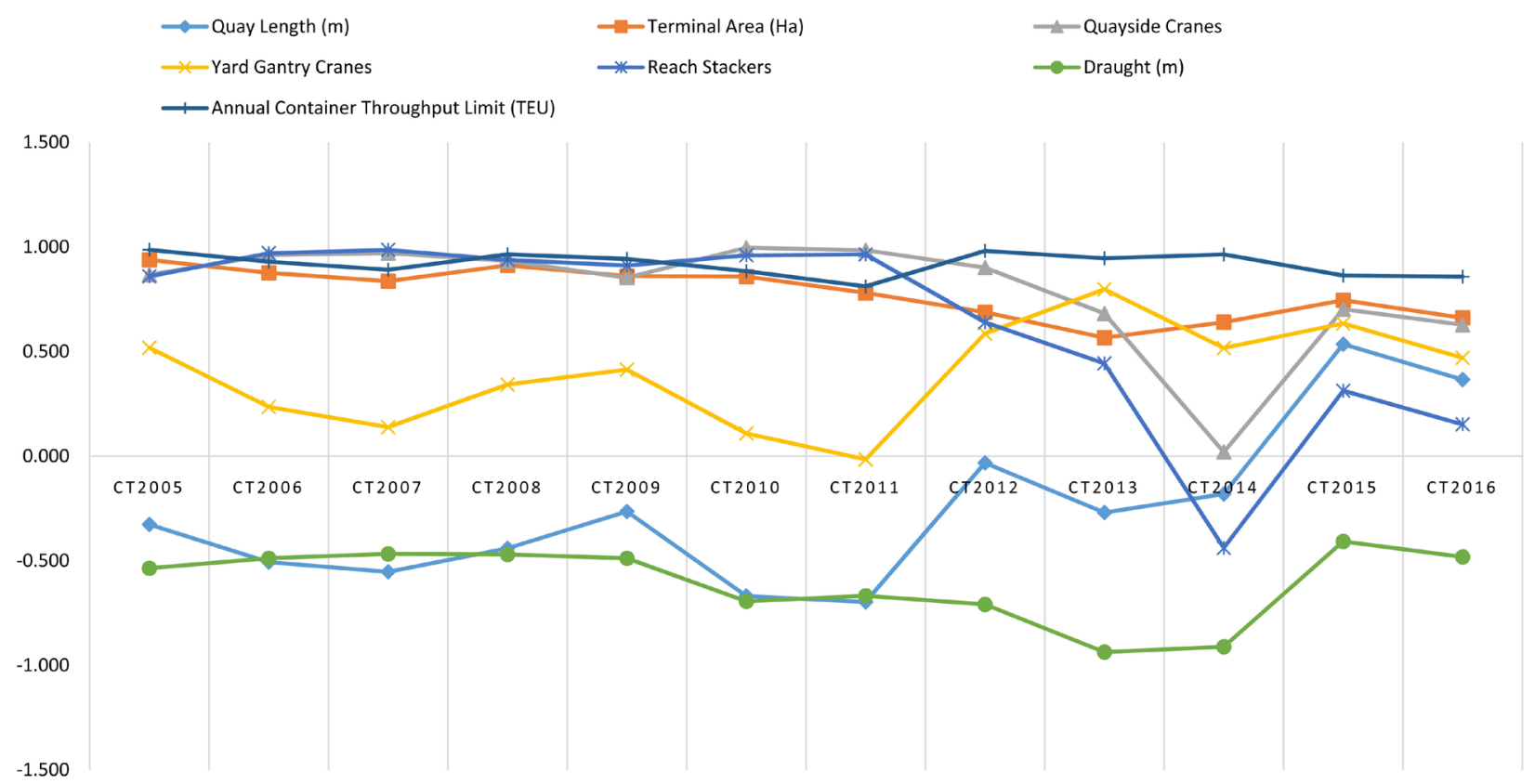

Figure 1. Container throughput vs. input variables correlation, from year 2005-2016. Source: Processed by the Author. 


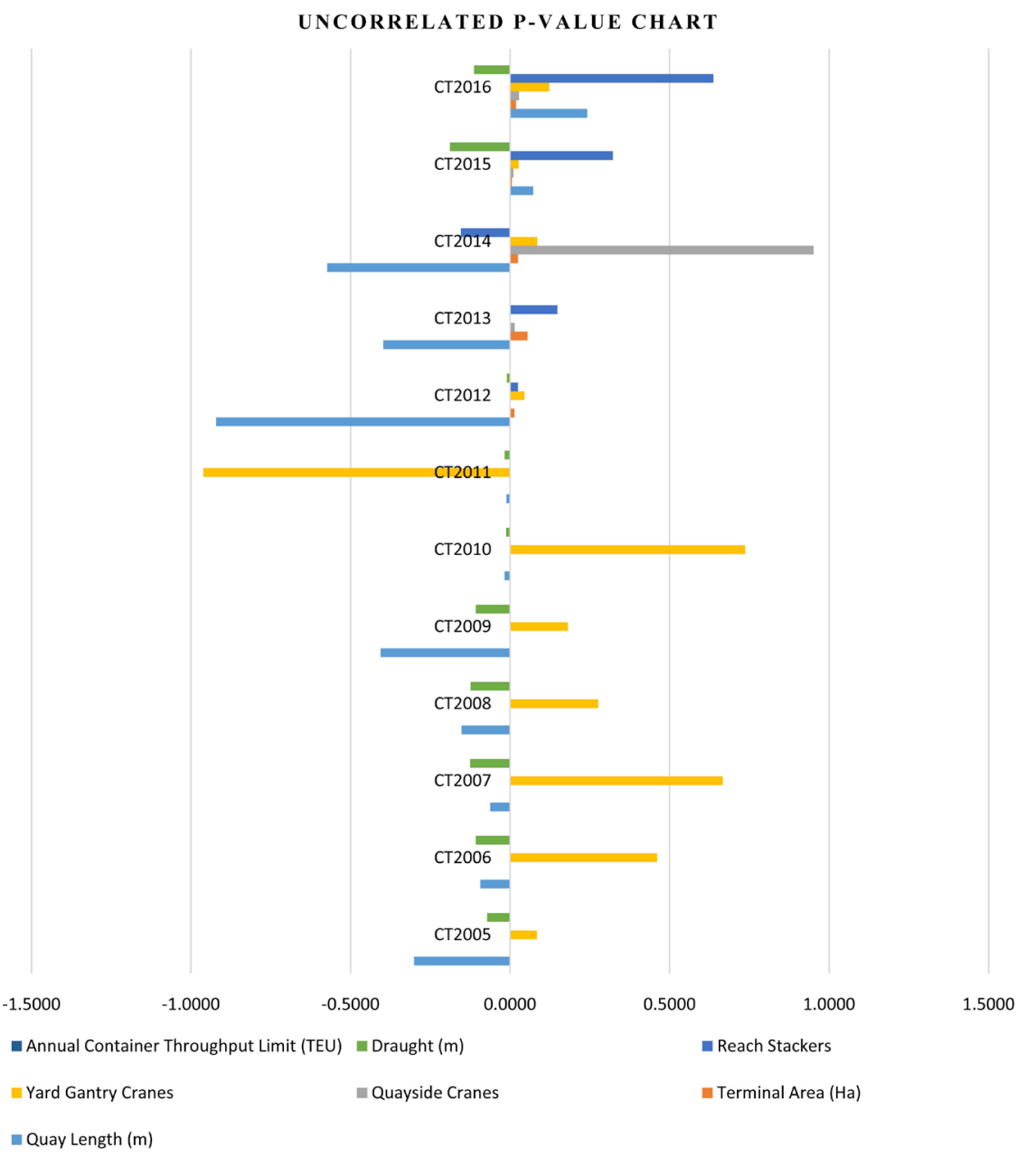

Figure 2. Uncorrelated variable probability value chart, from year 2005-2016. Source: Processed by the Author.

\section{Conclusion}

The West African port landscape has evolved rapidly since the turn of the century despite a slow start in adjusting to the requirements of modern shipping liners and containerized trade. Out of the 12 West African ports, the present study measured the relative efficiency of five major commercial ports from the year 2005 to 2016. These were the ports of Abidjan, Cotonou, Lagos, Lomé, and Tema. The occurrence of no correlation for non-significant variables and negative correlation for the significant variables throughout time results from the fact that these variables are not fully utilized. In other words, they are not efficiently used to boost container throughput on a scale basis. The research also found that a pandemic or security threats can easily impact seaports activities. Consequently, the present study demonstrated that the discrepancy in correlation among input variables from 2013 to 2016 is on one hand explained by the Ebola outbreak which strucked the West African region, and on the other hand, explained by the terrorist threats the region has experienced, which has therefore hampered all trade. A deviation from the most productive scale size (MPSS), by 
$10.47 \%$ for instance, if the quay length is well utilized (meaning that more containership is berthing at the ports), then a positive relationship could be established with the container throughput throughout time (implying an infrastructure project development as throughput increases with time). On the opposite side, a negative but significant correlation in this case, can express that the ports are too small regarding the activities they perform. Outcome highlights that three ports (Tema, Lagos and Lomé) exhibited constant returns to scale (CRS). In addition, other two ports (Abidjan and Cotonou) are operating at increasing returns to scale. Due to their small size of production, they should enhance their efficiency by selecting a scaling up strategy that will increase their scale of operations. Consequently, the study found that the container throughput at these five ports was more dependent on the terminal area, the quayside cranes, reach stackers and the annual container throughput limit.

\section{Conflicts of Interest}

The authors declare no conflicts of interest regarding the publication of this paper.

\section{References}

[1] Adam, S. (1982) The Wealth of Nations Books I-III. Penguin Classics, London.

[2] Talley, W.K. (2009) Port Economics. Routledge, London and New York. https://doi.org/10.4324/9780203880067

[3] Slack, B. (1985) Containerization, Inter-Port Competition and Port Selection. Maritime Policy and Management, 12, 293-303. https://doi.org/10.1080/03088838500000043

[4] Hayuth, Y. (1988) Rationalization and Deconcentration of the U.S. Container Port System. The Professional Geographer, 40, 279-288.

https://doi.org/10.1111/j.0033-0124.1988.00279.x

[5] The World Bank (2017) World Bank Data. https://data.worldbank.org

[6] Statista (2017) Container Shipping-Statistics \& Facts. Transportation \& Logistics, Water Transport. https://www.statista.com/topics/1367/container-shipping

[7] Rodrigue, J.-P. (2017) The Geography of Transport Systems. Routledge Taylor and Francis Group, New York.

[8] van Dyck, G.K. (2016) An Empirical Assessment of Inter-Port Competition in West Africa towards Hub Port Selection. Doctoral Dissertation, Shanghai Maritime University, Transport Engineering Economics and Management, Shanghai.

[9] Kalgora, B. (2019) Strategic Container Ports Competitiveness Analysis in West Africa Using Data Envelopment Analysis (DEA) Model. Open Journal of Business and Management, 7, 680-692. https://doi.org/10.4236/ojbm.2019.72046

[10] Van de Voorde, E. and Winkelmans, W. (2002) A General Introduction to Port Competition and Management. In: Huybrechts, M. and Meers, H., Eds., Port Competitiveness: An Economic and Legal Analysis of the Factors Determining the Competitiveness of Seaports, The National Academies of Sciences, Engineering, and Medicine, Washington DC, 1-16.

[11] MOW (2015) West Africa. Maps of World. 
http://www.mapsofworld.com/africa/regions/western-africa-map.html

[12] ECOWAS (2015) Member States. Economic Community of West African States. http://www.ecowas.int/member-states

[13] AFDB (2015) Economic Transformation. African Development Bank, Abidjan. http://www.afdb.org/en/blogs/measuring-the-pulse-of-economic-transformation-in -west-africa

[14] Kalgora, B. (2019) Intermodal Terminal Localisation Using a Linear Programming Approach: The Case Study of Togo and West African Landlocked Countries. Journal of Transportation Technologies, 9, 215-231. https://doi.org/10.4236/jtts.2019.92014

[15] van Dyck, G.K. (2015) The Drive for a Regional Hub Port for West Africa: General Requirements and Capacity Forecast. International Journal of Business and Economics Research, 4, 36-44. https://doi.org/10.11648/j.ijber.20150402.13

[16] Monteiro, M. (2014) Productivity in the Container Port Business-Case Study of the Mediterranean Range. University of Antwerp, Antwerp.

[17] Notteboom, T. and Rodrigue, J. (2008) Containerisation, Box Logistics and Supply Chains: The Integration of Ports in Liner Shipping Networks. Maritime Economics and Logistics, 10, 1152-1174. https://doi.org/10.1057/palgrave.mel.9100196

[18] Wu, Y.C.J. and Goh, M. (2010) Container Port Efficiency in Emerging and More Advanced Markets. Transportation Research Part E, 46, 1030-1042. https://doi.org/10.1016/j.tre.2010.01.002

[19] Demirel, B., Cullinane, K. and Haralambides, H. (2012) Container Terminal Efficiency and Private Sector Participation. In: Talley, W.K., Ed., The Blackwell Companion to Maritime Economics, Blackwell Publishing Ltd., Hoboken, 571-598. https://doi.org/10.1002/9781444345667.ch28

[20] Liu, Q. (2010) Efficiency Analysis of Container Ports and Terminals. PHD Thesis, Centre for Transport Studies, University College of London, London.

[21] Porter, M. (1990) The Competitive Advantage of Nations. Harvard Business Review, 68, 73-93. https://doi.org/10.1007/978-1-349-11336-1

[22] van Dyck, G.K. (2015) Assessment of Port Efficiency in West Africa Using Data Envelopment Analysis (DEA). American Journal of Industrial and Business Management, 5, 208-218. https://doi.org/10.4236/ajibm.2015.54023

[23] Padilla, M. and Eguia, R. (2010) Relative Efficiency of Seaports in Mindanao. 11th National Convention on Statistics (NCS), Manila, 11-13 October 2010, 1-15.

[24] Fried, H.O., Lovell, C.A.K. and Schmidt, S.S. (2008) The Measurement of Productive Efficiency and Productivity Growth. Oxford University Press, New York. https://doi.org/10.1093/acprof:oso/9780195183528.001.0001

[25] Anguibi, C.F.C. (2015) Analyzing the Operational Efficiency of Container Ports in Sub-Saharan Africa. Open Journal of Social Sciences, 3, 10-17. https://doi.org/10.4236/jss.2015.310002

[26] Coelli, T. (1996) A Guide to FRONTIER Version 4.1: A Computer Program for Frontier Production Function Estimation. University of New England Department of Econometrics, CEPA Working Paper 96/07, Armidale.

[27] Cullinane, K.W.F., Song, D.W. and Ji, P. (2006) The Technical Efficiency of Container Ports; Comparing Data Envelopment Analysis and Stochastic Frontier Analysis. Transportation Research Part A: Policy and Practice, 40, 354-374. https://doi.org/10.1016/j.tra.2005.07.003

[28] Wang, T.F., Song, D.W. and Cullinane, K. (2003) Container Port Production Effi- 
ciency: A Comparative Study of DEA and FDH Approaches. Journal of the Eastern Asia Society for Transportation Studies, 5, 698-713.

[29] Martinez-Budria, E., Diaz-Armas, R., Navarro-Ibanez, M. and Ravelo-Mesa, T. (1999) A Study of the Efficiency of Spanish Port Authorities Using Data Envelopment Analysis. International Journal of Transport Economics, 26, 237-253.

[30] Tongzon, J. (2001) Efficiency Measurement of Selected Australian and Other International Ports Using Data Envelopment Analysis. Transportation Research Part A: Policy and Practice, 35, 113-128. https://doi.org/10.1016/S0965-8564(99)00049-X

[31] Degbe, S.A. (2017) An Empirical Study on Transit Traffic via West African Corridors: Case Study of Lomé-Ouagadougou. Master Thesis Dissertation, Shanghai Maritime University, Transport Planning and Management, Shanghai.

[32] Cullinane, K.P., Wang, T.F. and Cullinane, S.L. (2004) Container Terminal Development in Mainland China and Its Impact on the Competitiveness of the Port of Hong Kong. Transport Reviews, 24, 33-56. https://doi.org/10.1080/0144164032000122334

[33] Min, H. and Park, B. (2005) Evaluating the Inter-Temporal Efficiency Trends of International Container Terminals Using Data Envelopment Analysis. International Journal of Integrated Supply Management, 1, 258-277. https://doi.org/10.1504/IJISM.2005.005950

[34] Al-Eraqi, A.S., Barros, C.P., Mustaffa, A. and Khader, A.T. (2008) Efficiency of Middle Eastern and East African Seaports: Application of DEA Using Window Analysis. European Journal of Scientific Research, 23, 597-612.

[35] Ancor, S.-A., Javier, M.S., Tomás, S. and Lourdes, T. (2016) When It Comes to Container Port Efficiency, Are All Developing Regions Equal? Transportation Research Part A, 86, 56-77. https://doi.org/10.1016/j.tra.2016.01.018

[36] Roll, Y. and Hayuth, Y. (2006) Port Performance Comparison Applying Data Envelopment Analysis (DEA). Maritime Policy \& Management, 20, 153-161. https://doi.org/10.1080/03088839300000025

[37] Cullinane, K.P. and Wang, T.-F. (2006) The Efficiency of European Container Ports: A Cross-Sectional Data Envelopment Analysis. International Journal of Logistics. Research and Applications, 9, 19-31. https://doi.org/10.1080/13675560500322417

[38] Munisamy, S. and Singh, G. (2011) Benchmarking the Efficiency of Asian Container Ports. African Journal of Business Management, 5, 1397-1407.

[39] PMAWCA (2017). http://www.agpaoc-pmawca.org

[40] Sherman, H.D. and Zhu, J. (2006) Service Productivity Management Improving Service Performance Using Data Envelopment Analysis (DEA).

[41] Charnes, A., Cooper, W.W. and Rhodes, E. (1978) Measuring the Efficiency of Decision Making Units. European Journal of Operational Research, 2, 429-444. https://doi.org/10.1016/0377-2217(78)90138-8

[42] Banker, R.D., Charnes, A. and Cooper, W.W. (1984) Some Models for Estimating Technical and Scale Inefficiencies in Data Envelopment Analysis. Management Science, 30, 1078-1092. https://doi.org/10.1287/mnsc.30.9.1078

[43] Banker, R.D., Cooper, W.W., Seiford, L.M., Thrall, R.M. and Zhu, J. (2004) Returns to Scale in Different DEA Models. European Journal of Operational Research, 154, 345-362. https://doi.org/10.1016/S0377-2217(03)00174-7 


\section{Appendix}

Table A1. Data inputs and output variables.

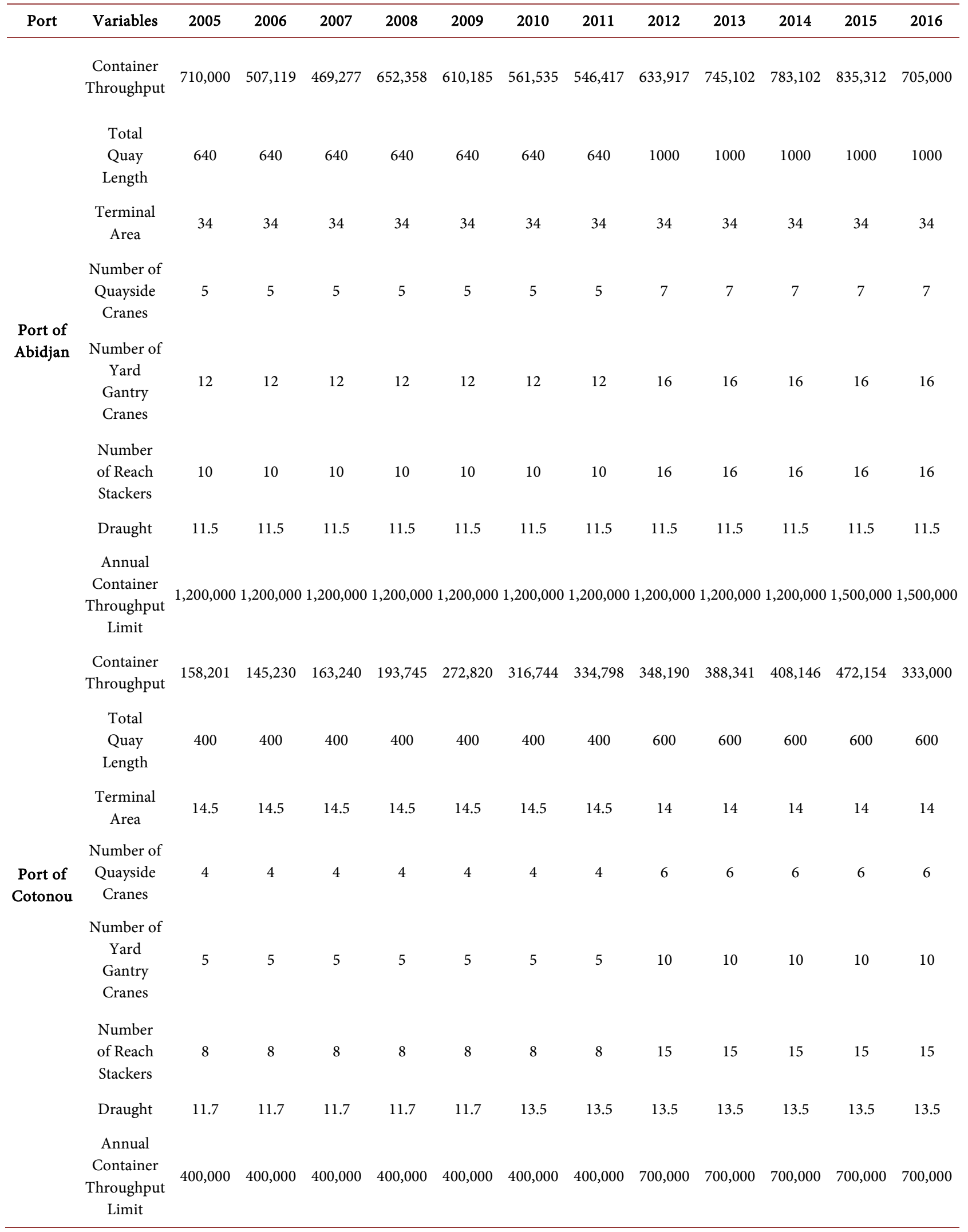




\section{Continued}

Container

Throughput $\quad 870,015 \quad 875,020 \quad 903,530 \quad 947,400 \quad 710,800 \quad 1,128,171 \quad 1,413,273 \quad 1,623,141 \quad 1,010,8361,062,389$ 1,156,287 1,335,470

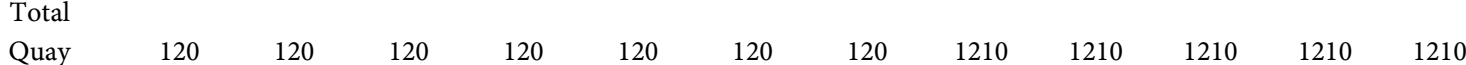

Length

$\begin{array}{lllllllllllll}\text { Terminal } & 45 & 45 & 45 & 45 & 45 & 45 & 45 & 42 & 42 & 42 & 42 & 42\end{array}$

Number

of Quayside

Cranes

Port of Number

Lagos of Yard

Gantry

Cranes

Number

of Reach

Stackers

$13 \quad 13$

$13 \quad 13$

13

Draught

$11.5 \quad 11.5 \quad 11.5 \quad 11.5$

Annual

Container

Throughput

$1,500,0001,500,0001,500,0001,500,0001,500,0001,500,0001,500,0002,000,0002,000,0002,000,0002,000,0002,000,000$

Limit

Container

Throughput

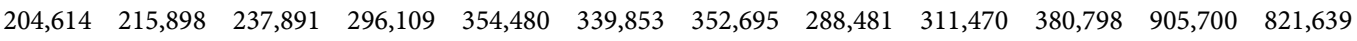

Total Quay

Length

$480 \quad 480$

Terminal

Area

$12 \quad 1$

Number of

Quayside

Cranes

Port of Number of

Yard Gantry

Cranes

Number

of Reach

Stackers

Draught

$$
14.5
$$$$
14.5
$$$$
14
$$$$
480
$$$$
48
$$$$
480-480
$$

$480 \quad 480$

Annual

Container

Throughput

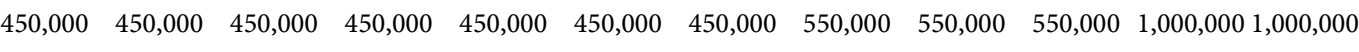
Limit

Port of Container

Tema Throughput

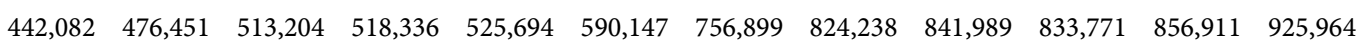

Total Quay

Length

$575 \quad 575 \quad 575$

$575 \quad 575$

575

$\begin{array}{llllll}575 & 575 & 575 & 575 & 575 & 575\end{array}$ 


\section{Continued}

\begin{tabular}{|c|c|c|c|c|c|c|c|c|c|c|c|c|}
\hline $\begin{array}{c}\text { Termina } \\
\text { Area }\end{array}$ & 14 & 14 & 14 & 14 & 14 & 14 & 14 & 14 & 14 & 14 & 14 & 14 \\
\hline $\begin{array}{c}\text { Number of } \\
\text { Quayside } \\
\text { Cranes }\end{array}$ & 5 & 5 & 5 & 5 & 5 & 5 & 5 & 8 & 8 & 8 & 8 & 8 \\
\hline $\begin{array}{c}\text { Number of } \\
\text { Yard } \\
\text { Gantry } \\
\text { Cranes }\end{array}$ & 3 & 3 & 3 & 3 & 3 & 3 & 3 & 12 & 12 & 12 & 12 & 12 \\
\hline $\begin{array}{l}\text { Number } \\
\text { of Reach } \\
\text { Stackers }\end{array}$ & 11 & 11 & 11 & 11 & 11 & 11 & 11 & 14 & 14 & 14 & 14 & 14 \\
\hline Draught & 11.5 & 11.5 & 11.5 & 11.5 & 11.5 & 11.5 & 11.5 & 11.5 & 11.5 & 11.5 & 11.5 & 11.5 \\
\hline $\begin{array}{c}\text { Annual } \\
\text { Container } \\
\text { Throughput } \\
\text { Limit }\end{array}$ & 650,000 & 650,000 & 650,000 & 650,000 & 650,000 & 650,000 & 650,000 & $1,200,000$ & $1,200,000$ & $1,200,000$ & $1,200,000$ & $1,200,000$ \\
\hline
\end{tabular}

Source: Port Management Association of West \& Central Africa (2017). 